\title{
Anti-apoptotic role and clinical relevance of neurotrophins in diffuse large B-cell lymphomas
}

Lydie Dubanet ${ }^{1,6}$, Hafidha Bentayeb ${ }^{1,6}$, Barbara Petit ${ }^{2}$, Agnès Olivrie ${ }^{3,4}$, Sofiane Saada ${ }^{1}$, Miguel A de la Cruz-Morcillo ${ }^{1}$, Fabrice Lalloué ${ }^{1}$, Marie-Pierre Gourin ${ }^{3,4}$, Dominique Bordessoule ${ }^{3,4,5}$, Nathalie Faumont ${ }^{5}$, Manuela Delage-Corre ${ }^{2}$, Anne-Laure Fauchais ${ }^{1}$, Marie-Odile Jauberteau ${ }^{1}$ and Danielle Troutaud ${ }^{*}, 1$

${ }^{1}$ EA3842, Facultés de Médecine et de Pharmacie, Université de Limoges, 2 rue du Docteur Marcland, 87025 Limoges Cedex, France; ${ }^{2}$ Laboratoire d'Anatomie-Pathologique, CHU de Limoges, 2 Avenue Martin Luther King, 87000 Limoges Cedex, France; ${ }^{3}$ Structure Régionale de Référence des Lymphomes du Limousin, CHU de Limoges, 2 Avenue Martin Luther King, 87000 Limoges Cedex, France; ${ }^{4}$ Service d'Hématologie Clinique, CHU de Limoges, 2 Avenue Martin Luther King, 87000 Limoges Cedex, France and ${ }^{5}$ UMR CNRS 7276, Facultés de Médecine et de Pharmacie, Université de Limoges, 2 rue du Docteur Marcland 87025, Limoges Cedex, France

Background: Diffuse large B-cell lymphoma (DLBCL) is a fatal malignancy that needs to identify new targets for additional therapeutic options. This study aimed to clarify the clinical and biological significance of endogenous neurotrophin (nerve growth factor (NGF) and brain-derived neurotrophic factor (BDNF)) in DLBCL biopsy samples and cell lines.

Methods: We analysed expression of NGF, BDNF, and their receptors (Trk, p75 $5^{N T R}$ ) in 51 biopsies and cell lines by immunohistochemistry, immunofluorescence, and western blotting. To investigate the biological role of BDNF/TrkB/p75 $5^{\mathrm{NTR}}$ axis, effects of neurotrophin signalling inhibition were determined on tumour cell survival and vascular endothelial growth factor (VEGF) secretion. The pharmacological pan-Trk inhibitor K252a was used for in vitro and in vivo studies.

Results: A BDNF/TrkB axis was expressed in all biopsies, which was independent of the germinal centre B-cell (GCB)/non-GCB profile. p $75^{\mathrm{NTR}}$, TrkB, and BDNF tumour scores were significantly correlated and high NGF expression was significantly associated with MUM1/IRF4, and the non-GCB subtype. Diffuse large B-cell lymphoma cell lines co-expressed neurotrophins and their receptors. The full-length TrkB receptor was found in all cell lines, which was also phosphorylated at Tyr-817. p75 ${ }^{\mathrm{NTR}}$ was associated to Trk and not to its cell death co-receptor sortilin. In vitro, inhibition of neurotrophin signalling induced cell apoptosis. K252a caused cell apoptosis, decreased VEGF secretion, and potentiated rituximab effect, notably in less rituximab-sensitive cells. In vivo, K252a significantly reduced tumour growth and potentiated the effects of rituximab in a GCB-DLBCL xenograft model.

Conclusions: This work argues for a pro-survival role of endogenous neurotrophins in DLBCLs and inhibition of Trk signalling might be a potential treatment strategy for rituximab resistant subgroups.

Diffuse large B-cell lymphomas (DLBCL) are highly aggressive non-Hodgkin lymphomas (NHL). They are subdivided into two major prognostically significant subtypes, germinal centre B-cell (GCB) and activated B-cell (ABC) type, which are respectively of better and worse prognostic. GCB lymphoma gene-expression profile clustered with normal germinal centre B cells. By contrast, ABC lymphomas arise from $B$ cells at a plasmablastic stage, just before germinal centre exit, and therefore express genes that are

*Correspondence: Dr D Troutaud; E-mail: danielle.troutaud@unilim.fr

${ }^{6}$ These authors contributed equally to this work.

Received 13 February 2015; revised 11 June 2015; accepted 22 June 2015; published online 18 August 2015

(c) 2015 Cancer Research UK. All rights reserved 0007-0920/15 
frequently expressed in mature plasma cells (Alizadeh et al, 2000; Rosenwald et al, 2002; Wright et al, 2003). Although the Akt pathway is constitutively activated in most tumour cells and B-NHL cell lines (Arranz et al, 1996; Suzuki et al, 2007), constitutive activation of the NF- $\kappa \mathrm{B}$ pathway is crucial for the survival of ABC-DLBCL cells but not GCB-DLBCL cells (Davis et al, 2001; Lam et al, 2005). Those lymphomas present an important clinical challenge. Despite significant survival improvement of patients obtained by combining a monoclonal anti-CD20 antibody, rituximab, with chemotherapy (R-CHOP immunochemotherapy), a subset of patients does not initially respond and several responsive patients develop rituximab resistance (Rezvani and Maloney, 2011).

Neurotrophins (NTs) among with the nerve growth factor (NGF) and the brain-derived neurotrophic factor (BDNF) are a family of structurally and functionally related growth factors that are widely expressed in a variety of tissues including the immune system (Vega et al, 2003). Neurotrophins are synthesised as proforms (proNTs), and both forms are secreted and exert biological activities (Teng et al, 2010). The actions of NTs are mediated by three receptor classes: the common p75 neurotrophin receptor $\left(\mathrm{p} 75^{\mathrm{NTR}}\right.$ ), the tropomyosin-related kinase receptors (TrkA for NGF and TrkB for BDNF), and the pro-NT receptor, sortilin (Reichardt, 2006). Trk receptors have also distinct isoforms that affect their function. In humans three major isoforms of TrkB are expressed, the full-length signal-transducing receptor TrkB-TK (or gp145TrkB) and two C-terminal truncated receptors thus lacking the tyrosine kinase domain, TrkB-T1 (or gp95TrkB) and TrkB-TShc (De Santi et al, 2009). Binding of NTs to the full-length TrkB receptor (TrkB-TK) triggers autophosphorylation of tyrosine residues in the intracellular kinase domain, followed by the activation of several survival signalling cascades, such as the phosphatidylinositol 3-kinase (PI3K)/Akt, MAPK, and PLC- $\gamma$ pathways. As opposite, binding of NTs to $\mathrm{p} 75^{\mathrm{NTR}}$ signals apoptosis, which involves activation of $c$-jun $\mathrm{N}$-terminal kinase (JNK) and caspases. However, NTs binding to $\mathrm{p} 75^{\mathrm{NTR}}$ also promotes activation of NF- $\kappa \mathrm{B}$, thereby promoting NF- $\kappa \mathrm{B}$-dependent cell survival signalling (Reichardt, 2006). Indeed, $\mathrm{p} 75^{\mathrm{NTR}}$ signalling is very complex. The receptors exist as dimers but an emerging consensus is that p $75^{\mathrm{NTR}}$ interacts with several co-receptors (as sortilin) and multiple ligands with important physiological consequences (Barker, 2007; Forsyth et al, 2014). Notably, in vivo and in vitro data have clearly indicated that $\mathrm{p} 75^{\mathrm{NTR}}$ and Trk receptors functionally interact, but the precise means by which this occurs has remained unresolved. It is well established that $\mathrm{p} 75^{\mathrm{NTR}}$ potentiates Trk signalling and notably TrkA at least in part by enhancing NGF binding to the TrkA receptor (for review, see Barker, 2007). The work of Wehrman et al (2007) provides key insights into the structural and kinetic issues concerning p $75^{\text {NTR }}$ and TrkA interactions in NGF binding. Their structural data suggest the possibility of a ternary complex $\mathrm{p} 75^{\mathrm{NTR}} / \mathrm{NGF} / \mathrm{TrkA}$, yet the biochemical data indicate that this complex does not form in living cells. It was proposed that TrkA and $\mathrm{p} 75^{\mathrm{NTR}}$ likely communicate through convergence of downstream signalling pathways and/or shared adaptor molecules, rather than through direct extracellular interactions. As contrast sortilin, an intracellular transport protein for NTs and proNTs, forms a high-affinity coreceptor complex with $\mathrm{p} 75^{\mathrm{NTR}}$ involved in the cell death effect of proNTs (Nykjaer et al, 2004). Previous studies in our laboratory showed, for the first time in B cell lines that an autocrine BDNF production is upregulated by stress culture conditions and exerts an anti-apoptotic effect through the sortilin pathway (Fauchais et al, 2008). Moreover, we also reported that GCB-DLBCL cell lines secrete NT that can be modified by culture conditions (serum deprivation) or treatment with rituximab (Bellanger et al, 2011). We hypothesised that NTs signalling could have a potential autocrine/ paracrine role in the clinical heterogeneity of human DLBCL.
Angiogenesis and the pro-angiogenic growth factor vascular endothelial growth factor (VEGF) have a known role in solid neoplasia, and there is increasing evidence that they also have a role in hematolymphoid neoplasia. Of note, VEGF could have a dual role in lymphomagenesis: as a paracrine angiogenic factor and as an autocrine growth factor (Gratzinger et al, 2007). Although hypoxia-induced HIF- $1 \alpha$ up regulation is the primary stimulus for VEGF production, aberrant activation of the PI3K and NF- $\kappa \mathrm{B}$ pathways can also contribute to increase HIF- $1 \alpha$ in normoxic conditions and notably in malignant lymphoma cells (Qiao et al, 2010; Karar and Maity, 2011). Interestingly in DLBCLs, tumour cells from patients co-expressed VEGF and its receptors VEGFR1 and VEGFR2, suggesting an autocrine loop for VEGF in lymphomagenesis (Wang et al, 2004; Gratzinger et al, 2008).

The aim of the present study was to evaluate neurotrophin functionality in $\mathrm{ABC}$ and $\mathrm{GCB}$-like cell lines and their possible association with clinicopathological variables in DLBCLs. As $\mathrm{BDNF} / \mathrm{TrkB}$ activation of the PI3K/mTOR pathway can lead to an increase in HIF- $1 \alpha$ that stimulates VEGF production (Nakamura et al, 2006), we also examined the potential relationship between NTs and VEGF secretion in DLBCL cell lines. Finally, we investigated in vivo the efficacy of Trk pharmacological inhibition combined or not with rituximab in a GCB-DLBCL xenograft model.

\section{MATERIALS AND METHODS}

Patient samples. Fifty-one cases of DLBCL treated in the haematology department of Dupuytren Hospital (Limoges, France) were collected from the 'Tumorothèque' of Dupuytren Hospital. Tumours were classified according to the World Health Organization classification (Swerdlow et al, 2008). DLBCL cases were then categorised as GCB or non-GCB subtype according to the Hans algorithm based on CD10, Bcl-6, and MUM1 expression (Hans et al, 2004). Clinical data of the patients were reviewed and are summarised for all patients in Table 1. This study was conducted after approval of the local ethics committee ( $\mathrm{N}^{\circ}$ 98-2012-23). All patients have been informed of the use of their tissue samples in research studies.

Immunohistochemistry. Immunohistochemical studies were performed as previously described (Troutaud et al, 2010) using Envision Kit (Dako Denmark A/S, Glostrup, Denmark). The antiNGF, anti-BDNF, anti-p75 ${ }^{\mathrm{NTR}}$, and anti-TrkB were purchased from Santa Cruz Biotechnology (Santa Cruz, Dallas, CA, USA), anti-TrkA from R\&D (Minneapolis, MN, USA), mouse isotypic control IgG1 from Cell Signaling (Beverly, MA, USA), and rabbit isotypic control was from Sigma (Sigma Aldrich, Saint Louis, MO, USA). Validation of the specificity of the antibodies used for the IHC assays has been previously done (Bellanger et al, 2011). The staining intensity was scored from 0 to 4 as follows: 0 , negative; 1 , weak; 2, moderate; 3, strong; 4, very strong. Furthermore, to compare the expression of NGF, BDNF and/or TrkA, TrkB, p $75^{\mathrm{NTR}}$ with clinical and pathological parameters, samples were grouped in high (staining intensity $>$ median immunohistochemical score) and low-expression groups (staining intensity $\leqslant \cap$ median immunohistochemical score). Section stainings were analysed independently by DT and an hematopathologist (BP or MCD) who were blinded to each other's scores, and without knowledge of clinical information. In case of disagreement, the staining results were reanalysed by the observers on a multihead microscope until consensus was reached.

Human B cell lines and cell cultures. The human GCB-like DLBCL cell lines, SUDHL4, and SUDHL6, were obtained from Deutsche Sammlung von Mikroorganismen und Zellkulturen (DSMZ, Braunschweig, Germany) and the two ABC-like DLBCL 
Table 1. Baseline patient clinical characteristics

\begin{tabular}{|c|c|}
\hline Characteristic & Number of patients $(n=51)$ \\
\hline Age (range) & $63 \pm 15(29-89)$ \\
\hline$\leqslant 60$ & 18 \\
\hline$>60$ & 33 \\
\hline $\operatorname{Sex}(M / F)$ & $32 / 19$ \\
\hline GCB & $29(57 \%)$ \\
\hline $\begin{array}{l}\text { Ann Arbor } \\
\text { Stage I/II } \\
\text { Stage III/IV }\end{array}$ & $\begin{array}{l}15 \\
14\end{array}$ \\
\hline $\begin{array}{l}\text { IPI } \\
\text { Low/low-intermediate }(\leqslant 2) \\
\text { Intermediate-high/high }(>2)\end{array}$ & $\begin{array}{l}19 \\
10\end{array}$ \\
\hline Non-GCB & 22 (43\%) \\
\hline $\begin{array}{l}\text { Ann Arbor } \\
\text { Stage I/II } \\
\text { Stage III/IV }\end{array}$ & $\begin{array}{c}8 \\
14\end{array}$ \\
\hline $\begin{array}{l}\text { IPI } \\
\text { Low/low-intermediate }(\leqslant 2) \\
\text { Intermediate-high/high }(>2)\end{array}$ & $\begin{array}{c}9 \\
13\end{array}$ \\
\hline Serum LDH level $>1 \times$ normal & $18(35 \%)$ \\
\hline Therapy regimen & R-CHOP \\
\hline 5-Year overall survival & $69 \%$ \\
\hline $\begin{array}{l}\text { Abbreviations: } M \text {, male; } F \text {, female; GC } \\
\text { dehydrogenase. }\end{array}$ & B, germinal centre B cell; LDH, lactate \\
\hline
\end{tabular}

cell lines, OCI-LY3, and OCI-LY10, were a gift of Pr Feuillard (UMR CNRS 7276, Limoges University) with the kind agreement of Louis M Staudt (National Cancer Institute, USA). The cell lines were grown in RPMI 1640 medium (Lonza, Basel, Switzerland) supplemented with $10 \%$ heat-inactivated fetal bovine serum (Thermo Scientific HyClone, Logan, UT, USA), $100 \mathrm{U} \mathrm{ml}^{-1}$ penicillin, $100 \mu \mathrm{g} \mathrm{ml}^{-1}$ streptomycin (Gibco Invitrogen Corporation, Carlsbad, CA, USA) at $37^{\circ} \mathrm{C}$ in a humidified atmosphere containing $5 \% \mathrm{CO}_{2}$. For the viability tests, cells were incubated with: various concentrations of rituximab $\left(1-20 \mu \mathrm{g} \mathrm{ml}^{-1}\right.$, MabThera, stock $10 \mathrm{mg} \mathrm{ml}^{-1}$, a generous gift from CHRU Dupuytren of Limoges, Pharmacie centrale), K252a (350 nM; Alomone Labs, Jerusalem, Israel), pro-BDNF (1-10 $\mathrm{ng} \mathrm{ml}^{-1}$, Alomone Labs), neutralising anti-BDNF $\left(15 \mu \mathrm{g} \mathrm{ml}^{-1}\right.$, Promega, Madison, WI, USA), exogenous BDNF (100 $\mathrm{ng} \mathrm{ml}^{-1}$, Promega), anti-p $75^{\text {NTR }}$ neutralising antibody (1-10-100 $\mathrm{ng} \mathrm{ml}^{-1}$, clone ME20.4, Merck KGaA, Darmstadt, Germany) alone or in combination.

Cell viability assay. Cellular viability was assessed using the colorimetric XTT (sodium 3' ${ }^{\prime}$-[1-(phenylaminocarbonyl)-3,4-tetrazolium]-bis(4-methoxy-6-nitro) benzene sulfonic acid hydrate)assay (Cell Proliferation Kit II, XTT Roche) as previously reported (Bellanger et al, 2011).

Analysis of apoptosis. Apoptosis was determined using the propidium iodide (PI)/Annexin-V-FITC double staining method (kit Beckman Coulter, Immunotech, Marseille, France) as previously described (Bellanger et al, 2011). This method effectively distinguishes apoptotic cells from necrotic cells. Apoptotic cells exhibited intense green (FITC) and negative or intermediate red (PI) fluorescence (early and late stages of apoptosis, respectively). Necrotic cells exhibited strong green and red fluorescence. Cells were analysed with a FACS Calibur flow cytometer (Becton Dickinson, Heidelberg, Germany) acquiring 10000 events gated on light scatter properties (forward $v s$ side: FSC/SSC) to eliminate debris and cellular aggregates.
Western blotting and immunoprecipitations. Western blotting was performed as described previously (Bellanger et al, 2011). Rabbit anti-BDNF, anti-NGF, anti-NT3, anti-p $75^{\mathrm{NTR}}$, goat anti-sortilin, and mouse anti-PARP-1 antibodies were purchased from Santa Cruz Biotechnology. Mouse anti-TrkB, anti-TrkA, and anti-TrkC antibodies were purchased from R\&D Systems. Anti-phospho TrkB (pY817) and anti-phospho-TrkC (Y820) were purchased from Abcam (Epitomics, Burlingame, CA, USA) and anti-phospho-TrkA (Y490) from Cell Signalling. Protein-loading control was performed with anti- $\beta$ actin Ab (Sigma). Visualisation of immunocomplexes was accomplished using the Immobilon Western Chemiluminescent HRP Substrate (Millipore, Darmstadt, Germany). Western blots were scanned using a bioimaging system (Genesnap; Syngene Europe, Cambridge, UK).

Co-immunoprecipitations were performed in accordance with the manufacturer's instructions (Catch and Release kit, Millipore) with $500 \mu \mathrm{g}$ of proteins and anti-p $75^{\mathrm{NTR}}$ for $1 \mathrm{~h}$ at room temperature. Finally immunoprecipitates were subjected to SDS-polyacrylamide gel electrophoresis, before analysis by western blotting (with anti-Trk, anti-sortilin and anti-p $75^{\mathrm{NTR}}$ ).

Immunofluorescence microscopy. Diffuse large B-cell lymphoma cells were challenged with antibodies against Trk, BDNF, NGF, $\mathrm{p} 75^{\mathrm{NTR}}$, and/or sortilin and analysed by immunofluorescence as previously described (Bellanger et al, 2011). Pictures were captured using a Leica microscope and a Leica digital camera (Leica Microsystems, Wetzlar, Germany). Images were processed using Leica IM500 Image Manager.

Cell supernatant VEGF immunoassay. Growth medium was collected and VEGF-A levels were determined using the human VEGF ELISA kit (PeproTech, Rocky Hill, CT, USA) according to the manufacturer's recommendations. All tests were performed in duplicate.

In vivo Xenografts. All animal studies were conducted in accordance with the guidelines established by the internal Institutional Animal Care and Use Committee (CREEAL $\mathrm{N}^{\circ}$ 2-07-2012). Four-weeks-old SCID mice (CB17.SCID) were supplied by Janvier Labs (Le Genest-Saint-Isle, France). For in vivo K252a efficacy, we used a DLBCL xenograft model. SCID mice were injected with $1 \times 10^{7}$ SUDHL4 cells subcutaneously. After the tumours had become established ( $\sim 6$ weeks after tumour inoculation) mice were divided (day 0 ) into treatment and control groups (at least five mice per group). Intraperitoneal administration of K252a dissolved in physiological saline $\left(0.5 \mathrm{mg} \mathrm{kg}^{-1}\right)$ was performed every 3 days for 3 weeks. Rituximab was administered i.p., alone or in combination of $\mathrm{K} 252 \mathrm{a}$, at a dose of $25 \mathrm{mg} \mathrm{kg}^{-1}$ twice a week. For negative controls, treatment with vehicle alone was used. Animals weighted between 20 and $26 \mathrm{~g}$ on day of treatment. All animals were ear-tagged and monitored individually throughout the experiment. The dose of K252a chosen for this experiment was based on published studies (Kawamura et al, 2010). Tumour volume $\left(\mathrm{cm}^{3}\right)$ was estimated by three weekly measurements of the length $(L)$, width $(W)$, and height $(H)$ of the tumour using the formula: volume $=L \times W \times H$. Mice were killed after 17 days of treatment. Tumour control samples were harvested and analysed by immunohistochemistry for their human origin (with anti-human CD20, Dako) and for NTs/p $75^{\mathrm{NTR}} /$ Trk expression. Moreover, western blotting analysis of Ki-67 expression (Dako), used to evaluate proliferative index, and of PARP cleavage for apoptosis induction were performed in some tumour samples from K252a-treated and vehicle control mice.

Statistical methods. Statistical analyses were performed using the StatView v5.0 software (Abacus Concepts, Berkeley, CA, USA). Significance between groups in the in vitro and xenograft studies were done using a Student's $t$-test. For the DLBCL patient samples, mean comparisons were based on Mann-Whitney $U$ test, and 
correlations between quantitative variables were assessed using the Spearman rank correlation coefficient $\rho . P<0.05$ was considered statistically significant.

\section{RESULTS}

DLBCL patient samples are characterised by a BDNF/TrkB axis and NGF expression is correlated with the $\mathrm{ABC}$ phenotype. We explored the pattern of NTs and their receptor expression in a cohort of 51 patients, with 29 were evaluated as GCB subtype and 22 as non-GCB (Table 1). This study was performed at the transcript and protein levels. mRNA for NGF, BDNF, TrkA, fulllength (TrkB145) and truncated TrkB, p75 ${ }^{\mathrm{NTR}}$, and sortilin were found in GCB and non-GCB biopsies (Supplementary Figure S1). Interestingly, only some patients had transcripts for the full-length TrkB receptor. We further examined all the biopsy samples at the protein level by immunohistochemistry as compared to normal reactive lymph nodes (RLNs). As expected, positive stainings for $\mathrm{BDNF}, \operatorname{TrkB}, \mathrm{p} 75^{\mathrm{NTR}}$, and with a lesser intensity for NGF and TrkA, were observed in numerous B cells within the germinal centres of RLNs (Figure 1A). Furthermore, as shown in Figures 1A and $\mathrm{B}, \mathrm{NTs}$ expression was seen in tumour B cells of all DLBCL samples as well as for TrkB with moderate-to-strong intensity staining. Of note, antibodies used for the protein study detect both forms of Trk receptors. In the majority, tumour samples were also moderately positive for TrkA and $\mathrm{p} 75^{\mathrm{NTR}}$. As for the RLNs, immunostainings show evidence of a $\mathrm{BDNF} / \mathrm{TrkB}$ axis in all DLBCL biopsy samples that was not significantly associated with a GCB or non-GCB phenotype. However, except for TrkA, stronger staining intensities were frequently observed with the non-GCB subtype of DLBCL patients (Figure 1A and B). Accordingly, NGF expression was correlated positively with Mum1, the ABC subtype marker and, as expected, with the non-GCB subtype $(P=0.008$ and $P=0.04$ respectively, Supplementary Table S2). Indeed, a higher expression of NGF was found statistically associated to Mum1-positive compared with Mum1-negative biopsies (Figure 1C and Supplementary Table S3). Finally TrkB expression was also positively correlated with those of BDNF and $\mathrm{p} 75^{\mathrm{NTR}}$ $(P=0.01$ and $P=0.006$ respectively, Supplementary Table S2). No significant correlation was found with clinicopathological parameters (data not shown).

Both GCB and ABC subtypes of DLBCL cell lines express neurotrophins and their receptors. Our clinical data suggest that NTs and Trk receptors may be functional in DLBCL and could be also associated with an aggressive phenotype. We therefore used DLBCL cell lines of ABC (OCI-LY3 and OCI-LY10) and GCB (SUDHL4 and SUDHL6) subtype to comparatively analyse modulation of NTs signalling on cell survival. NGF, BDNF, NT3, their high-affinity receptors $\operatorname{TrkA}, \operatorname{TrkB}$, and $\operatorname{TrkC}$ respectively, and their low-affinity receptor $\mathrm{p} 75^{\mathrm{NTR}}$ with its co-receptor sortilin are present in all GCB and ABC DLBCL cell lines tested. Differences in protein expression were found (Figure $2 \mathrm{~A}$ ) depending on cell lines but not on subtype of DLBCL. Trk receptors are produced even though the precursor form gp110 (TrkA110) predominated in the cell extracts. Notably a very-weak expression of mature form gp140 (TrkA140) was always found by western blot for all DLBCL cell lines. In contrast, TrkB was expressed as both full-length (kinase-intact, TrkB145) and truncated (kinase-deleted, TrkB95) isoforms. Membrane localisation of all receptors except sortilin was also demonstrated in GCB and ABC-like cells by immunofluorescence analysis performed without cell permeabilisation, as shown in Figure 2B for SUDHL6 and OCI-LY10. Interestingly, NT stainings performed on cell surface colocalised with Trk receptors that strongly suggests autocrine/paracrine loops involved in the regulation of tumour cell survival. Accordingly, basal activation notably of a fraction of TrkB was observed in DLBCL cell lines as demonstrated by the phosphorylation of Tyr-817 (Figure 2C). Furthermore, p $75^{\mathrm{NTR}}$ was found associated to TrkA and TrkB by co-immunoprecipitation analysis (Figure 2D) and not to sortilin. This association was also detected with the phosphorylated Trk as shown in Figure 2D for TrkB (phospho-TrkB Y817) suggesting a survival role for $\mathrm{p} 75^{\mathrm{NTR}}$ by $\mathrm{p} 75^{\mathrm{NTR}} /$ Trk interaction in growing cells, rather than an apoptotic function mediated by $\mathrm{p} 75^{\mathrm{NTR}} /$ sortilin association. Finally, we also
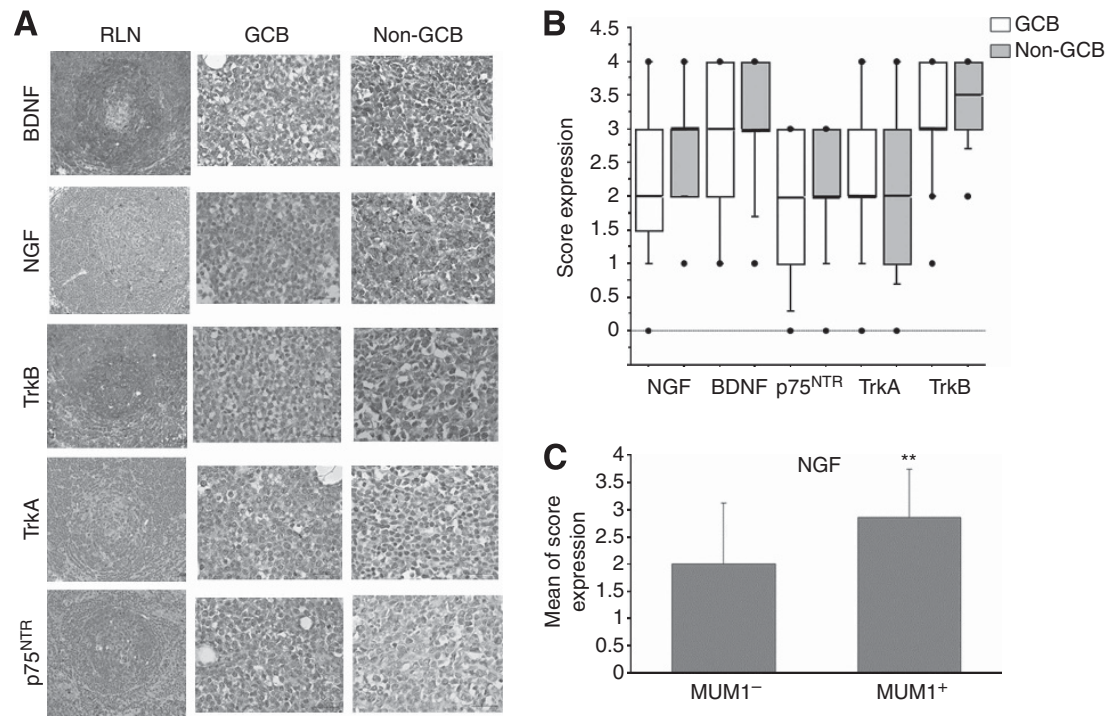

Figure 1. Immunohistochemical staining in DLBCL tumour samples. (A) Examples of NGF, BDNF, TrkA, TrkB, p75 ${ }^{N T R}$ stainings are done for a tumour biopsy of GCB and non-GCB DLBCL subtype $(\times 200)$ as compared with normal reactive lymph node (RLN). (B) Box-plots analysis showing distribution of total immunostaining scores determined in non-GCB tumour samples $(n=22)$ as compared with GCB $(n=29)$ DLBCL subtype. The horizontal line corresponds to the median value, the box length to the interquartile range. Box whiskers represent the maximum and minimum range excluding any extreme outliers (shown as dots). (C) Enhanced NGF expression is associated with MUM1-positive tumours. Results are expressed as means \pm s.d. of immunostaining NGF scores. ${ }^{\star \star} P<0.01$ (Mann-Whitney test). The full colour version of this figure is available at British Journal of Cancer online. 
A

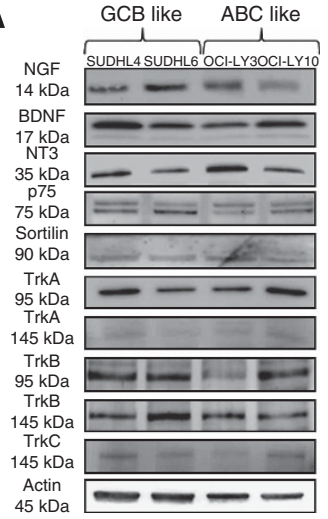

C

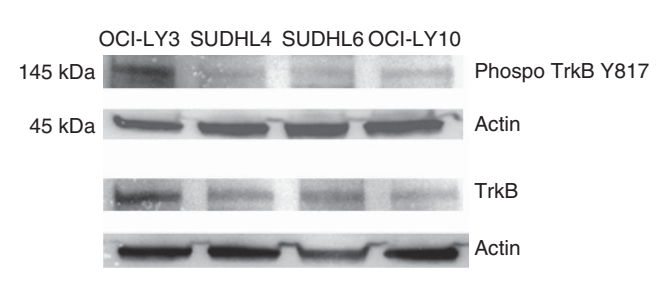

D

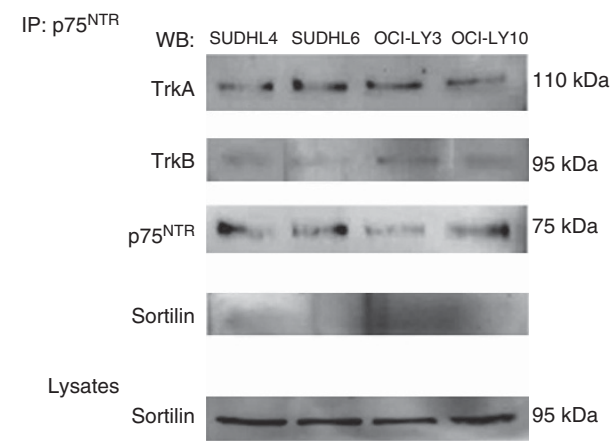

IP: $p$-TrkB

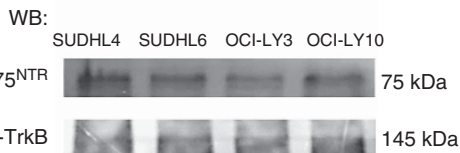

IP: $p 75^{\text {NTR }}$

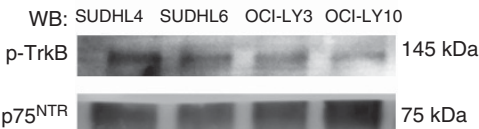

B
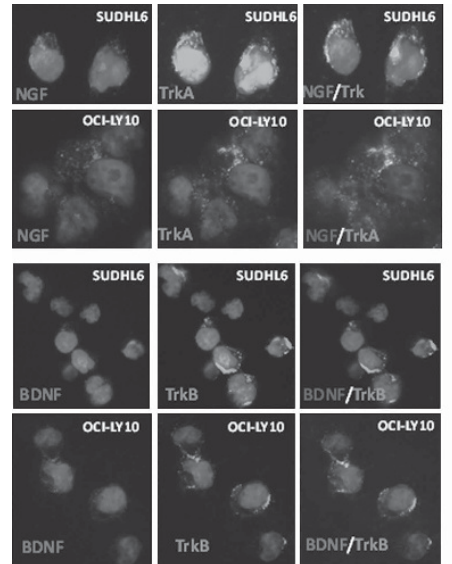
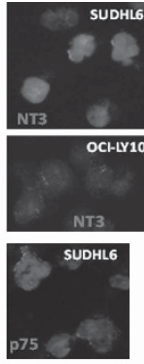
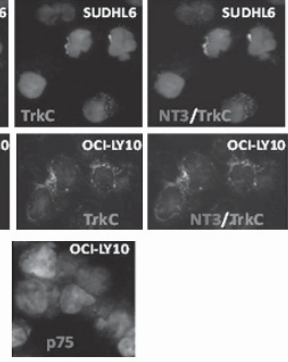
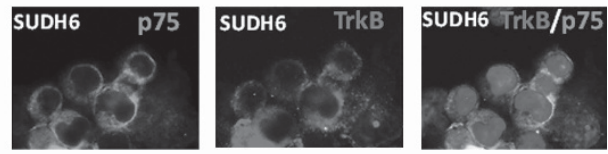

Figure 2. Comparative study of the pattern expression of neurotrophins and their receptors in GCB- and ABC-like DLBCL cell lines. (A) Analysis of NGF, BDNF, NT3, and their receptor expression in cell lysates of two GCB-like (SUDHL4 and SUDHL6) and two ABC-like (OCl-LY3 and OClLY10) cell lines, by western blotting after a 72 -h culture. Blots were re-probed with anti- $\beta$-actin as a loading control. Data are representative of at least four independent experiments. (B) Immunofluorescence staining performed without cell permeabilisation in DLBCL cell lines confirmed surface Trk receptors and neurotrophins or $75^{\mathrm{NTR}}$ expression on tumour B cells (revealed by Alexa Fluor 488, in green or Alexa Fluor 594 , in red). Merged image (yellow) revealed NTs/Trk or Trk/ p75 NTR co-localisation in DLBCL (in blue: DAPI staining). Data are done for SUDHL6 to compare with OCl-LY10 and are representative of at least three independent experiments. (C) TrkB-phosphotyrosine Y817 level was revealed by western blotting in all DLBCL cell lysates after a $72 \mathrm{~h}$ culture in basal conditions. (D) Protein lysates from all cell lines were subjected to immunoprecipitation (IP) with anti-p75 NTR or anti-phospho TrkB (Y817) followed by immunoblotting (western blotting) with indicated antibodies, showing p75 NTR interaction with Trk receptors but not with sortilin. Data are representative of three independent experiments. The full colour version of this figure is available at British Journal of Cancer online.

observed by immunofluorescence analysis some $\mathrm{p} 75^{\mathrm{NTR}} / \mathrm{Trk}$ co-localisation on the cell membrane of DLBCL cell lines, as it is shown for TrkB in SUDHL6 cells (Figure 2B).

Trk receptors are functional in DLBCL cell lines and their inhibition potentiates rituximab sensitivity of GCB as well as ABC cell lines. We have previously shown that Trk pharmacological inhibition induces apoptosis of a GCB cell line, SUDHL4, and synergises rituximab-induced cytotoxicity (Bellanger et al, 2011). ABC cell lines are known to be more resistant to therapeutic agents like rituximab. To test if Trk receptors promote differential effect on cell survival in DLBCL cell lines, we exposed ABC and GCB cells to a pharmacologic pan-Trk inhibitor, K252a, for $48 \mathrm{~h}$. Inhibition of Trk activation by K252a was confirmed in cell lines as shown in Figure 3A, for SUDHL4 and OCI-LY10, by the reduced phosphorylation of TrkB (Y817) as well as TrkA (Y490) and TrkC (Y820) receptors. Results showed that Trk inhibition significantly decreased cell viability of GCB cells (as shown for SUDHL4 in Figure $3 \mathrm{~B}$ ). This effect was observed also for the ABC cell line, OCI-LY10, even though it was only significant after $72 \mathrm{~h}$ of treatment. As expected no significant effect of rituximab was observed for the ABC cell line viability in contrast to the GCB. In contrast, rituximab induced apoptosis in the two cell lines but GCB cells were more sensitive than $\mathrm{ABC}$ subtype when considering the total apoptotic response and notably in presence of $1 \mu \mathrm{g} \mathrm{ml}^{-1}$ of rituximab (Figure 3C). Sensitivity of cells to K252a was also confirmed by analysis of cellular apoptosis as shown for SUDHL4 and OCI-LY10 in Figure 3C. Indeed, inhibition of Trk receptors with $\mathrm{K} 252 \mathrm{a}$ induced a significant apoptosis in OCI-LY10 with $41.6 \% \pm 7.4$ of apoptotic cells $v s 27.1 \% \pm 6.8$ in controls (means of five independent experiments, $P=0.003$ ). As expected, we also confirmed the significant apoptotic effect of K252a in SUDHL4 cells (with $38.6 \% \pm 16.5$ of apoptotic cells $v s 15 \% \pm 5.0$ in controls, means of five independent experiments, $P=0.004$ ). Interestingly, association of rituximab and K252a treatments induced a significant increase of SUDHL4 and OCI-LY10 apoptotic cell percentage as compared with rituximab alone (i.e., $42.2 \% \pm 13.4$ of apoptotic cells for SUDHL4 cells treated with K252a + rituximab $20 \mu \mathrm{g} \mathrm{ml}^{-1}$ vs $31.5 \% \pm 5.2$ for rituximab alone; $P=0.02$ and $51.6 \% \pm 6.1$ of apoptotic OCI-LY10 cells treated with K252a+ rituximab $20 \mu \mathrm{g} \mathrm{ml}^{-1}$ vs $41.2 \% \pm 7.6$ for rituximab alone $-P=0.04$. It is noteworthy that this synergistic apoptotic effect was also significantly observed, using the XTT assay, on SUDHL4 and OCILY10 cell viability within $48 \mathrm{~h}$ of culture when K252a was associated to the higher rituximab concentration (Figure $3 \mathrm{~B}$ ). We confirmed the higher apoptotic response obtained with combined 
A

B
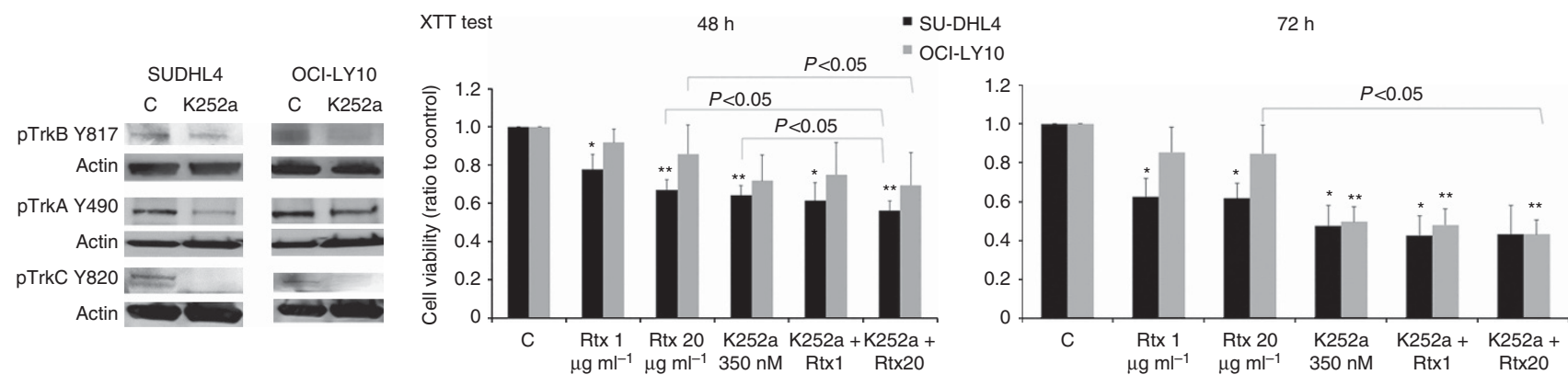

C
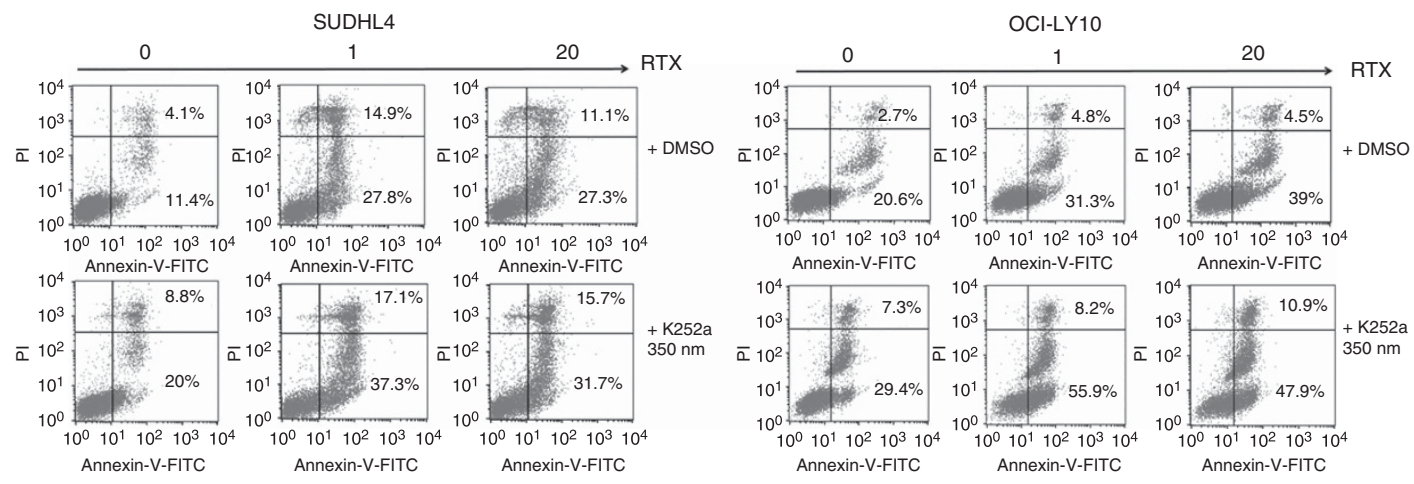

D

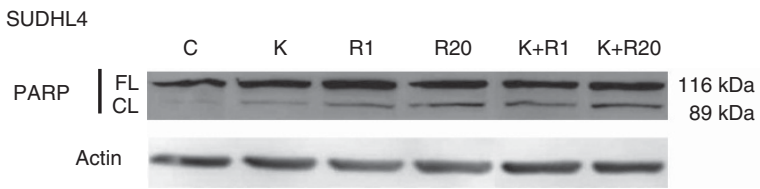

OCI-LY10

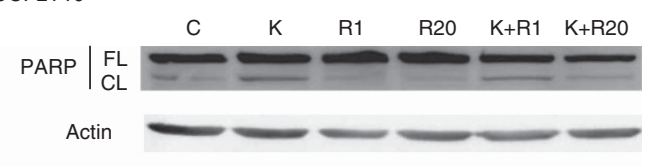

Figure 3. Pharmacological inhibition of Trk receptors sensitises the effect of rituximab in $A B C$ and GCB cell lines. GCB- (SUDHL4) and ABC (OCl-LY10)-like DLBCL cells were exposed to rituximab (RTX, 1 and $20 \mu \mathrm{g} \mathrm{ml}^{-1}$ ) with or without (C, controls) pharmacological inhibitor of Trk receptors, K252a (350 nm). (A) Inhibition of Trk signalling by K252a was confirmed in both cell lines by western blot analysis of TrkA, TrkB and TrkC receptor phosphorylation. (B) Viability of cells was evaluated during $48 \mathrm{~h}$ and $72 \mathrm{~h}$ using the XTT test and data are expressed as means $\pm \mathrm{s}$.d. of relative cell viability (ratio) related to control obtained from four independent experiments. ${ }^{*} P<0.01$ and ${ }^{* \star *} P<0.001$ when compared with DMSO controls (Student's t-test). (C) Apoptosis induced by rituximab and/or K252a was analysed by flow cytometry using the Annexin-V-FITC/PI dual staining. Ratio of early and late apoptotic (lower right quadrant) and necrotic (upper right quadrant) cells obtained after $36 \mathrm{~h}$ cell culture are expressed as cell percentages. Example of flow cytometric analysis representative of three experiments is done. (D) Rituximab (R) or/and K252a (K) induced apoptosis was also evaluated by western blot analysis of the poly (ADP-ribose) polymerase (PARP) cleavage after $48 \mathrm{~h}$ exposure in cell lysates. Data are representative of three independent experiments. Actin expression is done as loading reference. Abbreviations: $\mathrm{FL}$, full-length $(\mathrm{FL}) ; \mathrm{CL}$, cleaved PARP.

treatments in all GCB and $\mathrm{ABC}$ cell lines tested by detection of the cleaved form of the PARP-1, as shown for SUDHL4 and OCI-LY10 in Figure 3D. Thus, inhibition of Trk signalling can significantly improve the rituximab sensitivity of DLBCL cells, included the less sensitive rituximab $\mathrm{ABC}$ phenotype.

Evidence of a BDNF/TrkB/p75 ${ }^{\mathrm{NTR}}$ axis in GCB cell lines. Given the ability of K252a to inhibit survival of malignant DLBCL cells, and because full-length TrkB was produced by GCB- and ABC-like cell lines (as seen in Figure 2A), we next further explored the $\mathrm{BDNF}$ axis in these cells. Blocking endogenous BDNF with neutralising antibodies for $48 \mathrm{~h}$ decreased cell viability in both GCB cell lines SUDHL4 and SUDHL6 with more significance for SUDHL4 $(P<0.01$; Figure 4A). Moreover, exogenous pro-BDNF $\left(10 \mu \mathrm{g} \mathrm{ml}^{-1}\right)$ significantly decreases the cell viability $(P<0.05)$ of both GCB cell lines. Similar results could be observed with antagonistic anti-p $75^{\mathrm{NTR}}$ suggesting that $\mathrm{p} 75^{\mathrm{NTR}} / \mathrm{TrkB}$ interaction is involved in survival signalling activities (Figure 4A). However, no significant effect was found for the $A B C$ cell line tested (OCI-LY10). The apoptotic effects of pro-BDNF, anti-BDNF, and anti-p $75^{\mathrm{NTR}}$ neutralising antibodies were confirmed in cell lysates of GCB cell lines which revealed the proteolytic cleavage of
PARP-1 (Figure 4B). Of note, PARP cleavage was sometimes also observed notably in OCI-LY3 cells following exposition to exogenous pro-BDNF and antagonist p $75^{\text {NTR }}$ antibodies as compared with control. Collectively, our results suggest a pro-survival function of the $\mathrm{BDNF} / \mathrm{TrkB} / \mathrm{p} 75^{\mathrm{NTR}}$ axis in the DLBCL cells, which could be more decisive for the GCB phenotype.

Rituximab and Trk inhibition decrease VEGF secretion by DLBCL cells. Previous studies have shown that NTs, and notably BDNF/TrkB, modulate VEGF production (Nakamura et al, 2006). We quantified VEGF secretion in culture cell supernatant (Figures $4 \mathrm{C}$ and $\mathrm{D}$ ). We observed that VEGF production significantly varied between DLBCL cells rather than cell subtype, with for example $252 \pm 60$ and $190 \pm 41 \mathrm{pg} \mathrm{ml}^{-1}$ for SUDHL4 and OCI-LY10, respectively (data obtained from five independent assays). In contrast, the OCI-LY3 cell production was higher and more variable with VEGF production of $501 \pm 133 \mathrm{pg} \mathrm{ml}^{-1}$. No significant effect of anti-BDNF, exogenous pro-BDNF, and anti-p $75^{\text {NTR }}$ treatments was observed on VEGF secretion in the GCB and ABC cell lines tested (Figure 4C). However, when cells were exposed to the Trk inhibitor, K252a, we observed a strong 
A
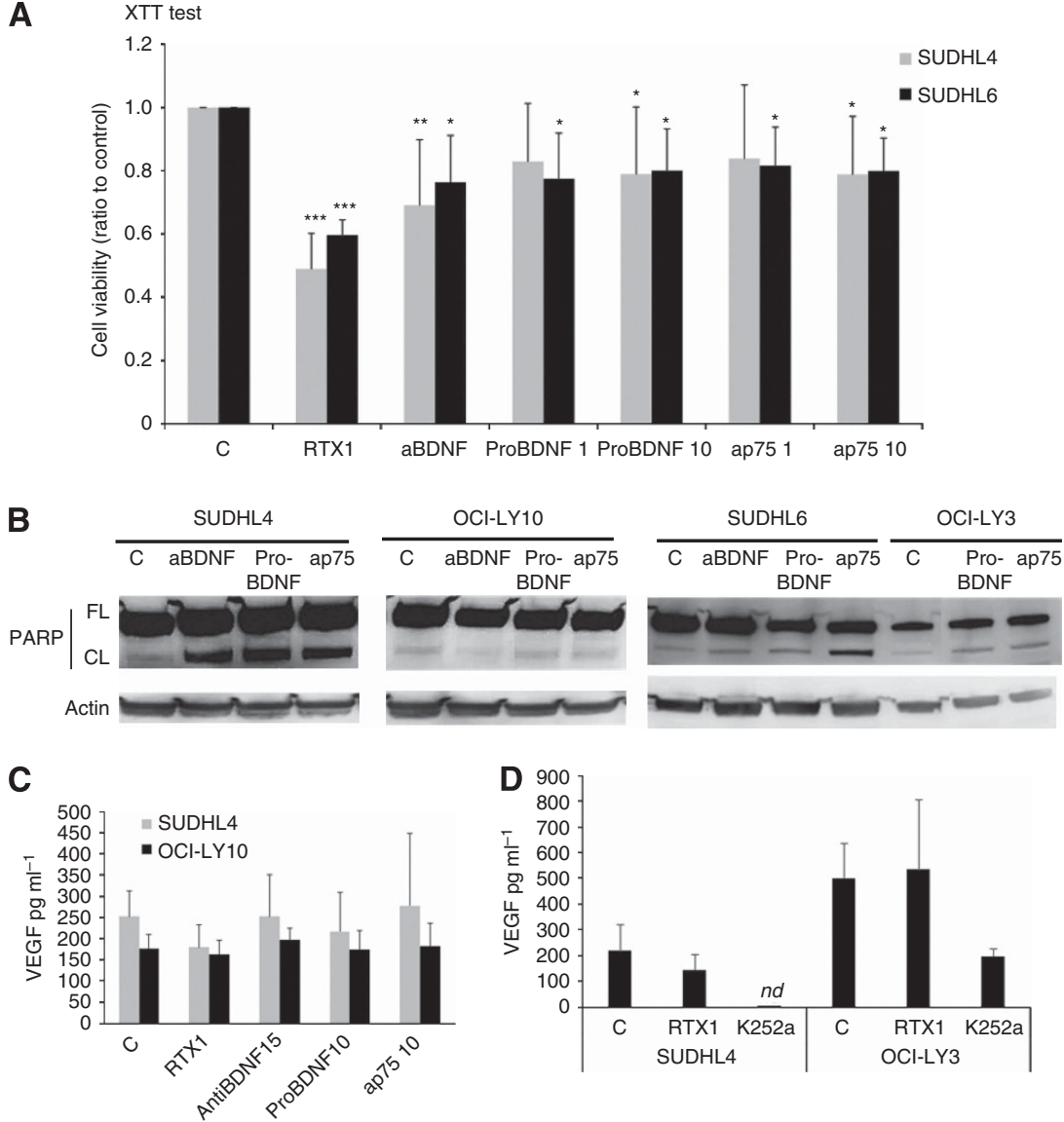

Figure 4. A BDNF neurotrophin axis is functional in DLBCL cell lines. Effect of neutralisation of endogenous $\mathrm{BDNF}$ (with anti-BDNF, $15 \mu \mathrm{g} \mathrm{ml}{ }^{-1}$ ) or

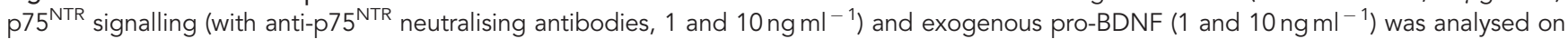
DLBCL cells during $72 \mathrm{~h}$. (A) Viability of cells exposed to anti-BDNF or pro-BDNF or anti-p75 ${ }^{\mathrm{NTR}}$ was evaluated in reference to rituximab response $\left(1 \mu \mathrm{g} \mathrm{ml}^{-1}\right)$ using the XTT metabolic test. Data obtained on GCB DLBCL cells after $72 \mathrm{~h}$ exposure are done as means $\pm \mathrm{s}$. d. of relative cell viability (ratio) related to control obtained from seven independent experiments. Student $t$-test was used to determine significance, ${ }^{\star} P<0.05$; ${ }^{\star \star} P<0.01$ and ${ }^{* \star} P<0.001$ when compared to controls (C). (B) Analysis of apoptosis revealed by western blotting detection of PARP cleavage. Data obtained for GCB cell lines (SUDHL4 and SUDHL6) compared to ABC cell lines (OCI-LY10 and OCI-LY3) are representative of three independent experiments. Actin is done as loading control. (C) VEGF secretion by DLBCL cells was quantified by ELISA in cell supernatants after $48 \mathrm{~h}$. Results are expressed as means \pm s.d. (pg ml ${ }^{-1}$ ) of at least four independent assays. ${ }^{\star \star} P<0.01$ when compared with controls (Student $t$-test). (D) Effect of Trk inhibition by K252a exposure was also analysed on VEGF secretion as compared to rituximab $\left(1 \mu \mathrm{g} \mathrm{ml}^{-1}\right)$ in SUDHL4 and OCl-LY3 supernatants. Results are expressed as means \pm s.d. $\left(\mathrm{pg} \mathrm{ml}^{-1}\right)$ of three independent assays. $\mathrm{nd}=$ non detectable.

decrease in VEGF secretion that reached levels, for SUDHL4 cells, lower than the threshold detection of the ELISA kit used for VEGF quantification. Furthermore, this effect was detected for all GCB and $\mathrm{ABC}$ cell lines tested (as shown for OCI-LY3 in Figure 4D). Finally, we showed that rituximab significantly decreased VEGF secretion. Interestingly, as shown in Figures $4 \mathrm{C}$ and D, this effect was only observed for the rituximab-sensitive GCB cell lines (i.e., SUDHL4) and not for the more resistant ABC cells (OCI-LY10 and OCI-LY3).

Trk receptor inhibition decreases tumour growth in a GCBDLBCL xenograft model. To investigate the potential in vivo efficacy of the pan-Trk pharmacologic inhibitor K252a, we used a DLBCL xenograft model. SCID mice were subcutaneously inoculated with SUDHL4 cells and tumours were allowed to establish for 6 weeks before treatment. As shown in Figure 5A, we confirmed by immunohistochemistry the human cell origin phenotype of the tumours by human CD20 expression, and the potential role of a BDNF/TrkB/p75 $5^{\mathrm{NTR}}$ axis as for human DLBCL biopsies. Tumours were significantly smaller in animals treated with $\mathrm{K} 252 \mathrm{a}$ than controls 12 days after treatment initiation $(P<0.05)$ and until the end of experiment $(P<0.01$ at 18 days post treatment). Compared with controls, treatment with K252a alone was shown to result in a $35 \%$ reduction in tumour volume $(3.52 \mathrm{vs}$ $5.36 \mathrm{~cm}^{3}$, Figure $\left.5 \mathrm{~B}\right)$. This effect was associated with a reduced Ki67 expression and an increase of PARP cleavage demonstrating apoptosis in tumour samples of K252a-treated mice in reference to vehicle controls (Figure 5C). As expected, rituximab administered i.p at $25 \mathrm{mg} \mathrm{kg}^{-1}$ per day twice a week was significantly more efficacious than K252a monotherapy, with $\sim 70 \%$ tumour growth rate inhibition at day18. However, combination therapy led to a significant improvement in tumour growth inhibition $v s$ rixitumab monotherapy, with a marked effect from day 3 to day $8(P<0.05)$, and $\sim 85 \%$ tumour growth rate inhibition at day18 (Figure $5 \mathrm{~B}$ ).

\section{DISCUSSION}

Several recent studies have provided evidence for a role of Trk pathway activation contributing to chemoresistance in tumourigenesis from non-neural tissues (Thiele et al, 2009; Akil et al, 2011; Okugawa et al, 2013). We have previously shown that GCB cell lines produce NTs (NGF, BDNF) that were modulated by culture conditions (Bellanger et al, 2011). This prompted us to evaluate the 


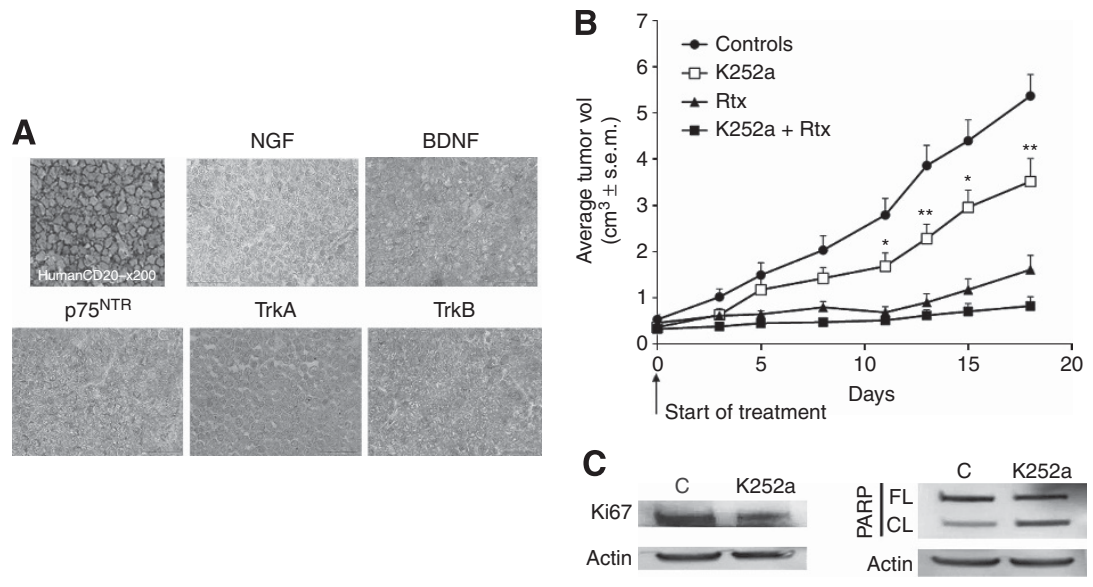

Figure 5. In vivo efficacy of K252a in a DLBCL xenograft model. For the GCB-DLBCL xenograft model, SCID mice were injected with $1 \times 10^{7}$ SUDHL4 cells subcutaneously. (A) The human SUDHL4 cell origin of tumours was confirmed by immunohistochemistry (with anti-human CD20) and representative stainings for NGF, BDNF, Trk, and $p 75^{\mathrm{NTR}}$ receptor are done $(\times 400)$. (B) After the tumours had become established $(\sim 6$ weeks after tumour inoculation), mice were treated with vehicle (Controls, $n=10), \mathrm{K} 252 \mathrm{a}\left(0.5 \mathrm{mg} \mathrm{kg}^{-1}, \mathrm{n}=10\right)$ or rituximab $\left(25 \mathrm{mg} \mathrm{kg}{ }^{-1}, n=5\right)$ or both agents $(n=8)$ for 3 weeks. Results are expressed as mean tumour volumes $\left(\mathrm{cm}^{3}\right) \pm$ s.d. ${ }^{\star}{ }^{\star \star} P<0.05$ and 0.01 respectively vs control group,

Student's t-test. (C) Example of a representative western blotting analysis of Ki67 expression and PARP cleavage is shown for tumour samples of K252a-treated mice compared with vehicle control mice. Actin is done as loading control. The full colour version of this figure is available at British Journal of Cancer online.

role of NTs and/or their receptors in tumour clinical heterogeneity of DLBCLs. We thus analysed their expression in a cohort of 51 DLBCL patients. Although a direct prognostic value was not established here, our results show that expression of NGF, BDNF and their Trk and $\mathrm{p} 75^{\mathrm{NTR}}$ receptors occur in DLBCL tumours. Furthermore, we report for the first time evidence of a strong $\mathrm{BDNF} / \mathrm{TrkB}$ phenotype in DLBCL that seems not in relation with cell-of-origin (COO) classification. In contrast, higher expression of NGF was associated with the non-GCB profile and notably the $\mathrm{ABC}$ phenotype characterised by prominent nuclear factor- $\kappa \mathrm{B}$ activation. Even though, as the immunohistochemistry Hans algorithm used for COO subtype determination is considered imperfect (Hans et al, 2004), these associations must to be confirmed in a larger cohort of patients. This finding is however consistent with a previous report showing, in normal stimulated B cells, NF- $\kappa \mathrm{B}$ activation as a key regulatory event for B-cell-derived NGF production (Heese, et al, 2006). This can explain the correlation observed in the present work, even if weakly, between high NGF expression and non-GCB subtype (mostly ABC) of DLBCLs. These data strongly suggest that autocrine/paracrine NT survival loops are involved in DLBCL tumour survival and aggressiveness. Moreover as TrkB, p75 ${ }^{\mathrm{NTR}}$, and BDNF expressions are correlated, we hypothesise a pro-survival $\mathrm{BDNF} / \mathrm{TrkB} / \mathrm{p} 75^{\mathrm{NTR}}$ axis in DLBCLs.

We therefore used DLBCL cell lines of $\mathrm{ABC}$ phenotype to evaluate neurotrophin functionality compared with GCB cells. Both GCB (SUDHL4/6) and ABC (OCI-LY3/10) cell lines express membranous TrkA, TrkB, and TrkC receptors, even if weakly, and produce their neurotrophin ligands NGF, BDNF, and NT3 respectively. Although antibodies used for immunofluorescence detected all forms of Trk receptors, a prominent expression of the TrkA precursor (TrkA110) and with a lesser extend truncated form of TrkB receptors (gp95TrkB) were detected by western blotting. Moreover, immunoprecipitation studies showed that $\mathrm{p} 75^{\mathrm{NTR}}$ is associated with TrkA110 and gp95TrkB receptors suggesting a biological role for these isoforms. Accordingly, a particular role of truncated form of TrkB (gp95) was previously reported in various B cell lines (Fauchais et al, 2008; Sniderhan et al, 2009). Furthermore, Trk receptors and notably $\operatorname{TrkB}$ was found phosphorylated at tyrosine 817 in all cell lines. This last data provides evidence for a membranous expression of the full-length TrkB receptor (gp145TrkB) and probably activation of PLC- $\gamma$ pathways in basal culture conditions. Interestingly $\mathrm{p} 75^{\mathrm{NTR}}$ and phospho-TrkB can be also co-immunoprecipitated suggesting they are certainly in close proximity to one another, which we proved by immunofluorescence co-localisation of $\mathrm{p} 75^{\mathrm{NTR}} / \mathrm{TrkB}$ at the plasma membrane of DLBCL cell lines. It has long been known that p $75^{\text {NTR }}$ potentiates Trk signalling and it was proposed that TrkA and $\mathrm{p} 75^{\mathrm{NTR}}$ communicate through convergence of downstream signalling pathways and/or shared adaptor molecules (Wehrman et al, 2007). The higher detection of truncated form of TrkB than TrkB145 itself, that we also observed at the transcript level in DLBCL tumour samples, has been recently observed in other nonneuronal cancers like for example breast tumours (Vanhecke et al, 2011). To date, little is known on the biological role of truncated TrkB, lacking the kinase domain, but recent works suggest cooperation between $\mathrm{p} 75^{\mathrm{NTR}}$ and truncated TrkB (TrkB-T1 or gp95TrkB). Indeed, TrkB-T1 was proposed to act as dominantnegative to $\mathrm{p} 75^{\mathrm{NTR}}$ in neurons (Michaelsen et al, 2010). Therefore, our results argue for an association of $\mathrm{p} 75^{\mathrm{NTR}}$ to activated Trk in DLBCL cell lines suggesting a synergistic signalling. Moreover, some $\mathrm{p} 75^{\mathrm{NTR}} /$ truncated Trk complex may interfere with the apoptotic signalling of $\mathrm{p} 75^{\mathrm{NTR}}$ which need to heterodimerise with the co-receptor sortilin (Nykjaer et al, 2004). This hypothesis is consistent with the fact that sortilin expression cannot be clearly observed at the cell membrane, neither in anti-p $75^{\text {NTR }}$ immunoprecipitates from cell lysates.

We also observed a co-localisation of Trk receptors and their respective ligands at the cell surface of DLBCL cells, suggesting that NTs mediate autocrine loops. Therefore we used the pan-Trk pharmacological inhibitor K252a, to evaluate the functionality of pro-survival Trk receptors expressed by our DLBCL cell lines (i.e., TrkA, TrkB, and TrkC). Results showed that inhibition of Trk signalling by K252a-induced apoptosis in cells of both DLBCL subtypes. These data confirm previous reports obtained in NHL cell lines including DLBCL lines (Sniderhan et al, 2009, Bellanger et al, 2011), but in the present study we compared the effect of Trk inhibition between ABC and GCB cell lines. Furthermore, we demonstrated a synergistic apoptotic effect of K252a with rituximab. Interestingly, this effect was significant even for the ABC cell lines tested (OCI-LY10 and OCI-LY3) which were less sensitive or unresponsive to rituximab as compare to the GCB lines. The apoptosis-induced response of B lymphoma cells exposed to rituximab is well known, and mechanisms imply 
inhibition of survival pathways that are constitutively activated in most of NHL like PI3K/Akt, Erk1/2, and NF- $\kappa$ B leading also to chemosensitisation (Suzuki et al, 2007; Weiner, 2010). Interestingly, these survival pathways are also activated by Trk signalling, (Teng et al, 2010) and thus targeted by the Trk pharmacologic inhibition, leading to a potential additive action with rituximab exposure. The less sensitivity of the ABC cells, OCI-LY10, as compared to GCB (SUDHL4 and SUDHL6) is in agreement with earlier studies, showing that, as for ABC DLBCLs, ABC lines are characterised by constitutive NF- $\kappa \mathrm{B}$ activation (Davis et al, 2001; Wright et al, 2003). The ability of NF- $\kappa \mathrm{B}$ to inhibit responses to cancer therapeutic agents was proposed to contribute to the refractory clinical behaviour of ABC DLBCLs (Baldwin, 2001). Interestingly, in the OCI-LY3 cell line, K252a was shown to induce a subnuclear distribution of NF- $\kappa \mathrm{B}$ resulting in the sequestration of RelA in the nucleolus, thereby inhibiting NF- $\kappa \mathrm{B}$-dependent gene transcription (Sniderhan et al, 2009). In this regard, the K252a sensitivity of the $\mathrm{ABC}$ cell lines suggests that targeting these Trk signalling may lead to improvements in rituximab-containing treatment protocols.

Since a clear full-length TrkB expression was found in all cell lines, we therefore evaluated the functionality of the BDNF/TrkB axis in these cells. Results obtained with neutralising anti-BDNF or anti-p $75^{\text {NTR }}$ as well as pro-BDNF cell exposure showed a cytotoxic effect with cell apoptosis that was revealed by the proteolytic cleavage of PARP-1 which is a pro-apoptotic signature (Chaitanya et al, 2010). This effect, however lower than the rituximab response, was only significant in the GCB cell lines. Accordingly, analysis of relative mRNA expression suggested a BDNF/TrkB pathway that could be more present in the two GCB cell lines tested as compared with the two ABC subtype (Supplementary Figure S2); in contrast, a significant marked expression of $\mathrm{p} 75^{\mathrm{NTR}}$ mRNA was found in the ABC cell line, OCI-LY3. These differences in NT phenotypes observed in DLBCL cell lines compared with primary tumours could result from multiple factors as the inaccuracy of current immunohistochemistry Hans algorithm, or culture conditions of $\mathrm{ABC}$ cell lines (i.e., RPMI culture medium with $10 \%$ SVF which is not always used in others studies for these cells). However, the limited set of cell lines for each subtype used in this work don't allow us to conclude on the differential expression and function of NT across GCB and ABC cell lines.

The cytotoxic effect observed with exogenous pro-BDNF suggests evidence of some $\mathrm{p} 75^{\mathrm{NTR}} /$ sortilin complex at cell membrane, which signalling may be enhanced by this treatment. To clarify $\mathrm{p} 75^{\mathrm{NTR}}$ function in DLBCL we recently performed p $75^{\text {NTR }}$ downregulation in GCB and ABC cell lines with shRNA. We significantly reduced levels of p $75^{\mathrm{NTR}}$ in SUDHL4, SUDHL6, and OCI-LY10 (Supplementary Figure S3), and this inhibition significantly increased rituximab sensitivity of the three cell lines. However, we did not observe reduction in cell viability without rituximab, as with antagonistic anti-p $75^{\mathrm{NTR}}$. Presumably we could not detect cell death in cells transfected with $\mathrm{p} 75^{\mathrm{NTR}}$ shRNA, as p $75^{\text {NTR }}$ expression was not completely abolished ( $\sim 50 \%$ of protein inhibition). Even though preliminary, these recent data confirm a survival function of $\mathrm{p} 75^{\mathrm{NTR}}$ in DLBCL cells that could be involved in rituximab resistance of some more aggressive subtype like ABC. Collectively results obtained by different inhibitions of NT signalling in the present work argue for a pro-survival BDNF/ $\mathrm{TrkB} / \mathrm{p} 75^{\mathrm{NTR}}$ axis in DLBCL cells that was also suggested by the DLBCL tumour sample results.

The tumour microenvironment has been shown to be an important prognostic factor in patients with DLBCL, and two stromal gene-expression signatures that predicted survival in $\mathrm{CHOP}$ and R-CHOP-treated patients were identified. The prognostically favourable stromal-1 signature reflects extracellularmatrix deposition and histiocytic infiltration. By contrast, the

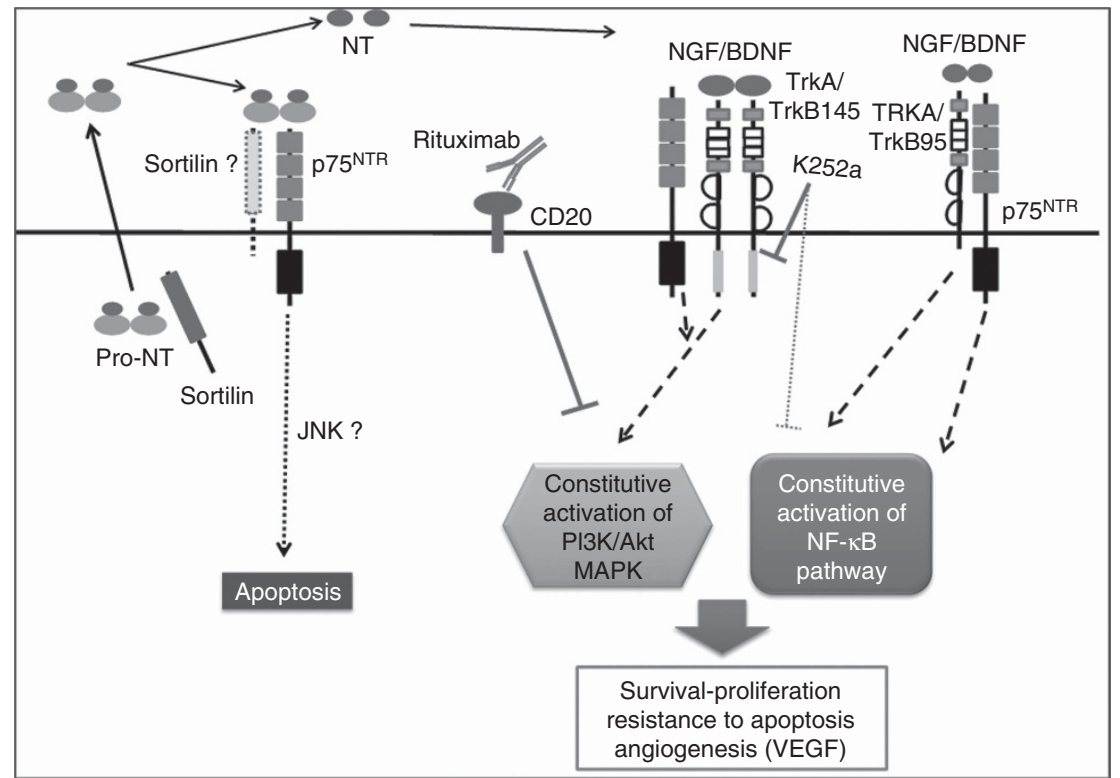

Figure 6. Schematic representation of a neurotrophin axis in the biology of DLBCL cells. Neurotrophins (NT) are produced as pro-neurotrophins (pro-NT) and secreted by tumour B cells. Enzymatic cleavage leads to the release of mature NTs in cell microenvironment that realise autocrine/ paracrine loops of regulation. In ABC phenotype, activation of the NF- $\kappa$ B pathway enhances the production of NGF. NT signalling (i.e., BDNF/ TrkB145) potentiates cell survival pathways and VEGF secretion that are already dependent of constitutively activated pathways in DLBCL cells (PI3K/Akt, MAPK and for ABC subtype the NF- $\kappa$ B pathway). This effect could lead to enhanced resistance to treatment. p75 NTR receptor should be involved in cell survival by its interaction with Trk receptor (i.e., full-length TrkB145 or truncated TrkB95) rather than in apoptosis by its sortilin association. Anti-CD20 therapy (i.e., rituximab) inhibits also the constitutively activated survival pathways (like PI3K-Akt) in B tumour cells leading in chemosensitisation to drug-induced apoptosis. Thus Trk pharmacological inhibition (i.e., K252a) can contribute to enhance cell sensitivity to rituximab therapy, notably for relative resistant phenotypes as ABC subtype of DLBCL. The full colour version of this figure is available at British Journal of Cancer online. 
prognostically unfavourable stromal-2 signature, including VEGFR2 receptor, reflects tumour blood-vessel density (Lenz et al, 2008). Indeed, VEGF was strongly detected in DLBCL tumour cells which co-express VEGF and its receptors VEGFR1 and VEGFR2, suggesting autocrine loops (Wang et al, 2004; Gratzinger et al, 2008). Of note, VEGF/VEGFR-mediated autocrine loops have been implied in the survival and growth of NHL cell lines (Wang et al, 2004). Interestingly, VEGFR2 involved in neovascularisation and not VEGFR1 expression predicts poor overall survival in DLBCL treated with immunochemotherapy (R-CHOP) (Gratzinger et al, 2010). Anti-VEGF therapies (bevacizumab) have been also evaluated in recent clinical studies. Results showed that bevacizumab might only be beneficial in DLBCL with high relative expression of endothelial markers and angiogenic regulators (Seymour et al, 2014). In the present work, we also focused on VEGF secretion. As expected, we detected VEGF secretion in all tested DLBCL cell supernatants. Interestingly, pharmacological inhibition of Trk signalling significantly reduced VEGF secretion in both groups, suggesting for the first time in DLBCLs a link between NTs and VEGF production. In addition our finding that rituximab only affects VEGF secretion of the rituximab-sensitive GCB cell lines indicates, for the first time, a relationship between rituximab-induced apoptosis and secretion of this growth factor. Activation of the PI3K/AKT/mTOR pathway, which is observed in the majority of human cancers including most of the DLBCLs, can increase VEGF secretion both by HIF- $1 \alpha$ dependent and independent mechanisms (Karar and Maity, 2011). As NGF-TrkA and/or BDNF/TrkB activation of the PI3K/mTOR pathway leads to an increase of HIF- $1 \alpha$ that stimulates VEGF promoter activity and transcription in neuroblastoma cells (Nakamura et al, 2006, 2011), we propose that Trk-signalling pathway contributes to VEGF secretion in DLBCL cells. Consistent with this hypothesis, rituximab by inhibiting the same survival pathway could lead, as Trk-signalling inhibition by K252a, to the inhibition of VEGF production that we observed in the present work for GCB cell lines. This effect could be prevented in ABC cell lines that continue to secrete VEGF even after rituximab exposure, by the constitutive activation of NF- $\kappa \mathrm{B}$ pathway known also to be involved in HIF- $1 \alpha$ activation (Karar and Maity, 2011).

Finally, inhibition of endogenous Trk signalling by K252a was evaluated with a GCB-DLBCL xenograft model. Data show a statistical reduction of tumour growth which was associated with a cytotoxic effect on tumour cells, as we demonstrated in the in vitro study. This effect was however lower than rituximab monotherapy. Blocking BDNF/TrkB signalling by K252a was recently shown to suppress tumour growth also in gastric cancer, but it did not affect 5-fluorouracil sensitivity (Okugawa et al, 2013). Interestingly, consistent with our in vitro studies, we demonstrate here for the first time that in combination regimen, pharmacological Trk inhibition potentiates the effects of rituximab monotherapy on established DLBCL xenografts. However, further mechanistic investigations will be necessary to precise if concomitant K252a and rituximab therapy result in synergistic or additive effects.

Altogether, our data show evidence for a pro-survival role of endogenous NTs in DLBCLs that could be involved in aggressive phenotypes. Notably, as we propose in Figure 6, our results indicate that inhibition of Trk signalling could be a potential treatment strategy for $\mathrm{ABC}$ subtype and subgroup of DLBCL depending to a large extent on angiogenesis via VEGF for tumour survival and proliferation.

\section{ACKNOWLEDGEMENTS}

We thank Brigitte Fournier (Laboratoire d'Anatomie-Pathologique CHU Limoges, France) and Maud Branchaud for technical supports and Dr Cornelia Wilson for reviewing the English version of this manuscript. This work was supported by Ligue Nationale Contre le Cancer (Comité Départemental de La Haute-Vienne) and CORC (Comité d'Orientation Recherche Cancer en Limousin).

\section{CONFLICT OF INTEREST}

The authors declare no conflict of interest.

\section{AUTHOR CONTRIBUTIONS}

Conception and design: DT, MOJ, and DB. Acquisition, analyse and interpretation of data: LD, HB, DT, BP, AO, MADLCM, FL, SS, MPG, MDC, and ALF. Drafting the article or revising it critically for important intellectual content: DT, NF, MOJ, and DB. Wrote the paper including design of figures: DT, LD, HB, and MADLCM. Final approval of the version to be published: DT, MOJ, NF, DB, and ALF.

\section{REFERENCES}

Akil H, Perraud A, Mélin C, Jauberteau MO, Mathonnet M (2011) Fine-tuning roles of endogenous brain-derived neurotrophic factor, TrkB and sortilin in colorectal cancer cell survival. PLoS One 6: e25097. Alizadeh AA, Eisen MB, Davis RE, Ma C, Lossos IS, Rosenwald A, Boldrick JC, Sabet H, Tran T, Yu X, Powell JI, Yang L, Marti GE, Moore T, Hudson Jr J, Lu L, Lewis DB, Tibshirani R, Sherlock G, Chan WC, Greiner TC, Weisenburger DD, Armitage JO, Warnke R, Levy R, Wilson W, Grever MR, Byrd JC, Botstein D, Brown PO, Staudt LM (2000) Distinct types of diffuse large B-cell lymphoma identified by gene expression profiling. Nature 403: 503-511.

Arranz E, Robledo M, Martínez B, Gallego J, Román A, Rivas C, Benítez J (1996) Incidence of homogeneously staining regions in non-Hodgkin lymphomas. Cancer Genet Cytogenet 87: 1-3.

Baldwin AS (2001) Control of oncogenesis and cancer therapy resistance by the transcription factor NF-kappaB. J Clin Invest 107: 241-246.

Barker PA (2007) High affinity not in the vicinity? Neuron 53: 1-4.

Bellanger C, Dubanet L, Lise MC, Fauchais AL, Bordessoule D, Jauberteau MO, Troutaud D (2011) Endogenous neurotrophins and Trk signalling in diffuse large B cell lymphoma cell lines are involved in sensitivity to rituximabinduced apoptosis. PLoS One 6: e27213.

Chaitanya GV, Steven AJ, Babu PP (2010) PARP-1 cleavage fragments: signatures of cell-death proteases in neurodegeneration. Cell Commun Signal 8: 31 .

Davis RE, Brown KD, Siebenlist U, Staudt LM (2001) Constitutive nuclear factor B $\kappa$ B activity is required for survival of activated B cell-like diffuse large B cell lymphoma cells. J Exp Med 194: 1861-1874.

De Santi L, Annunziata P, Sessa E, Bramanti P (2009) Brain-derived neurotrophic factor and TrkB receptor in experimental autoimmune encephalomyelitis and multiple sclerosis. J Neurol Sci 287: 17-26.

Fauchais AL, Lalloué F, Lise MC, Boumediene A, Preud'homme JL, Vidal E, Jauberteau MO (2008) Role of endogenous brain-derived neurotrophic factor and sortilin in B cell survival. J Immunol 181: 3027-3038.

Forsyth PA, Krishna N, Lawn S, Valadez JG, Qu X, Fenstermacher DA, Fournier M, Potthast L, Chinnaiyan P, Gibney GT, Zeinieh M, Barker PA, Carter BD, Cooper MK, Kenchappa RS (2014) p75 neurotrophin receptor cleavage by $\alpha$ - and $\gamma$-secretases is required for neurotrophinmediated proliferation of brain tumor-initiating cells. J Biol Chem 289: 8067-8085.

Gratzinger D, Zhao S, Marinelli RJ, Kapp AV, Tibshirani RJ, Hammer AS, Hamilton-Dutoit S, Natkunam Y (2007) Microvessel density and expression of vascular endothelial growth factor and its receptors in diffuse large B-cell lymphoma subtypes. Am J Pathol 170: 1362-1369.

Gratzinger D, Zhao S, Tibshirani RJ, Hsi ED, Hans CP, Pohlman B, Bast M, Avigdor A, Schiby G, Nagler A, Byrne Jr GE, Lossos IS, Natkunam Y (2008) Prognostic significance of VEGF, VEGF receptors, and microvessel density in diffuse large B cell lymphoma treated with anthracycline-based chemotherapy. Lab Invest 88: 38-47. 
Gratzinger D, Advani R, Zhao S, Talreja N, Tibshirani RJ, Shyam R, Horning S, Sehn LH, Farinha P, Briones J, Lossos IS, Gascoyne RD, Natkunam Y (2010) Lymphoma cell VEGFR2 expression detected by immunohistochemistry predicts poor overall survival in diffuse large $\mathrm{B}$ cell lymphoma treated with immunochemotherapy (R-CHOP). Br J Haematol 148: 235-244.

Hans CP, Weisenburger DD, Greiner TC, Gascoyne RD, Delabie J, Ott G, Müller-Hermelink HK, Campo E, Braziel RM, Jaffe ES, Pan Z, Farinha P, Smith LM, Falini B, Banham AH, Rosenwald A, Staudt LM, Connors JM, Armitage JO, Chan WC (2004) Confirmation of the molecular classification of diffuse large B-cell lymphoma by immunohistochemistry using a tissue microarray. Blood 103: 275-282.

Heese K, Inoue N, Sawada T (2006) NF-kappaB regulates B-cell-derived nerve growth factor expression. Cell Mol Immunol 3: 63-66.

Karar J, Maity A (2011) PI3K/AKT/mTOR Pathway in Angiogenesis. Front Mol Neurosci 4: 51.

Kawamura N, Kawamura K, Manabe M, Tanaka T (2010) Inhibition of brainderived neurotrophic factor/tyrosine kinase B signalling suppresses choriocarcinoma cell growth. Endocrinology 151: 3006-3014.

Lam LT, Davis RE, Pierce J, Hepperle M, Xu Y, Hottelet M, Nong Y, Wen D, Adams J, Dang L, Staudt LM (2005) Small molecule inhibitors of I $\kappa$ B kinase are selectively toxic for subgroups of diffuse large B-cell lymphoma defined by gene expression profiling. Clin Cancer Res 11: 28-40.

Lenz G, Wright G, Dave SS, Xiao W, Powell J, Zhao H, Xu W, Tan B, Goldschmidt N, Iqbal J, Vose J, Bast M, Fu K, Weisenburger DD, Greiner TC, Armitage JO, Kyle A, May L, Gascoyne RD, Connors JM, Troen G, Holte H, Kvaloy S, Dierickx D, Verhoef G, Delabie J, Smeland EB, Jares P, Martinez A, Lopez-Guillermo A, Montserrat E, Campo E, Braziel RM, Miller TP, Rimsza LM, Cook JR, Pohlman B, Sweetenham J, Tubbs RR, Fisher RI, Hartmann E, Rosenwald A, Ott G, Muller-Hermelink HK, Wrench D, Lister TA, Jaffe ES, Wilson WH, Chan WC, Staudt LM (2008) Stromal gene signatures in large-B-cell lymphomas. Lymphoma/Leukemia Molecular Profiling Project. N Engl J Med 359: 2313-2323.

Michaelsen K, Zagrebelsky M, Berndt-Huch J, Polack M, Buschler A, Sendtner M, Korte M (2010) Neurotrophin receptors TrkB.T1 and p75NTR cooperate in modulating both functional and structural plasticity in mature hippocampal neurons. Eur J Neurosci 32: 1854-1865.

Nakamura K, Martin KC, Jackson JK, Beppu K, Woo CW, Thiele CJ (2006) Brain-derived neurotrophic factor activation of TrkB induces vascular endothelial growth factor expression via hypoxia-inducible factor-1alpha in neuroblastoma cells. Cancer Res 66: 4249-4255.

Nakamura K, Tan F, Li Z, Thiele CJ (2011) NGF activation of TrkA induces vascular endothelial growth factor expression via induction of hypoxiainducible factor-1 $\alpha$. Mol Cell Neurosci 46: 498-506.

Nykjaer A, Lee R, Teng KK, Jansen P, Madsen P, Nielsen MS, Jacobsen C, Kliemannel M, Schwarz E, Willnow TE, Hempstead BL, Petersen CM (2004) Sortilin is essential for proNGF-induced neuronal cell death. Nature 427: 843-848.

Okugawa Y, Tanaka K, Inoue Y, Kawamura M, Kawamoto A, Hiro J, Saigusa S, Toiyama Y, Ohi M, Uchida K, Mohri Y, Kusunoki M (2013) Brain-derived neurotrophic factor/tropomyosin-related kinase B pathway in gastric cancer. $\mathrm{Br} J$ Cancer 108: 121-130.

Qiao Q, Nozaki Y, Sakoe K, Komatsu N, Kirito K (2010) NF- $\kappa$ B mediates aberrant activation of HIF-1 in malignant lymphoma. Exp Hematol 38: 1199-1208.

Reichardt B (2006) Neurotrophin-regulated signalling pathways. Philos Trans $R$ Soc Lond B Biol Sci 361: 1545-1564.

Rezvani AR, Maloney DG (2011) Rituximab resistance. Best Pract Res Clin Haematol 24: 203-216.

Rosenwald A, Wright G, Chan WC, Connors JM, Campo E, Fisher RI, Gascoyne RD, Muller-Hermelink HK, Smeland EB, Giltnane JM, Hurt EM,
Zhao H, Averett L, Yang L, Wilson WH, Jaffe ES, Simon R, Klausner RD, Powell J, Duffey PL, Longo DL, Greiner TC, Weisenburger DD, Sanger WG, Dave BJ, Lynch JC, Vose J, Armitage JO, Montserrat E, López-Guillermo A, Grogan TM, Miller TP, LeBlanc M, Ott G, Kvaloy S, Delabie J, Holte H, Krajci P, Stokke T, Staudt LM (2002) The use of molecular profiling to predict survival after chemotherapy for diffuse large-B-cell lymphoma. Lymphoma/Leukemia Molecular Profiling Project. N Engl J Med 346: 1937-1947.

Seymour JF, Pfreundschuh M, Trnĕný M, Sehn LH, Catalano J, Csinady E, Moore N, Coiffier B (2014) R-CHOP with or without bevacizumab in patients with previously untreated diffuse large B-cell lymphoma: final MAIN study outcomes. Haematologica 99: 1343-1349.

Sniderhan LF, Garcia-Bates TM, Burgart M, Bernstein SH, Phipps RP, Maggirwar SB (2009) Neurotrophin signalling through tropomyosin receptor kinases contributes to survival and proliferation of non-Hodgkin lymphoma. Exp Hematol 37: 1295-1309.

Suzuki E, Umezawa K, Bonavida B (2007) Rituximab inhibits the constitutively activated PI3K-Akt pathway in B-NHL cell lines: involvement in chemosensitization to drug-induced apoptosis. Oncogene 26: 6184-6193.

Swerdlow SH, Campo E, Harris NL, Jaffe ES, Pileri SA, Stein H, Jaffe ES (2008) WHO Classification of Tumours of Haematopoietic and Lymphoid Tissues. 4th edn. IARC Press: Lyon, France.

Teng KK, Felice S, Kim T, Hempstead BL (2010) Understanding proneurotrophin actions: recent advances and challenges. Dev Neurobiol 70: $350-359$.

Thiele CJ, Li Z, McKee AE (2009) On Trk-the TrkB signal transduction pathway is an increasingly important target in cancer biology. Clin Cancer Res 15: 5962-5967.

Troutaud D, Petit B, Bellanger C, Marin B, Gourin-Chaury MP, Petit D, Olivrie A, Feuillard J, Jauberteau MO, Bordessoule D (2010) Prognostic significance of BAD and AIF apoptotic pathways in diffuse large B-cell lymphoma. Clin Lymphoma Myeloma Leuk 10: 118-124.

Vanhecke E, Adriaenssens E, Verbeke S, Meignan S, Germain E, Berteaux N, Nurcombe V, Le Bourhis X, Hondermarck H (2011) Brain-derived neurotrophic factor and neurotrophin- $4 / 5$ are expressed in breast cancer and can be targeted to inhibit tumor cell survival. Clin Cancer Res 17: 1741-1752.

Vega JA, García-Suárez O, Hannestad J, Pérez-Pérez M, Germanà A (2003) Neurotrophins and the immune system. J Anat 203: 1-19.

Wang Y, Fei D, Vanderlaan M, Song A (2004) Biological activity of bevacizumab, a humanized anti-VEGF antibody in vitro. Angiogenesis 7: $335-345$.

Wehrman T, He X, Raab B, Dukipatti A, Blau H, Garcia KC (2007) Structural and mechanistic insights into nerve growth factor interactions with the TrkA and p75 receptors. Neuron 53: 25-38.

Weiner GJ (2010) Rituximab: mechanism of action. Semin Hematol 47: 115-123.

Wright G, Tan B, Rosenwald A, Hurt EH, Wiestner A, Staudt LM (2003) A gene expression-based method to diagnose clinically distinct subgroups of diffuse large B cell lymphoma. Proc Natl Acad Sci USA 100: 9991-9996.

This work is published under the standard license to publish agreement. After 12 months the work will become freely available and the license terms will switch to a Creative Commons AttributionNonCommercial-Share Alike 4.0 Unported License.

Supplementary Information accompanies this paper on British Journal of Cancer website (http://www.nature.com/bjc) 